\title{
Development of Rubita Media Based on QR Code with Strengthening the Character of Hard Work of Class IV Elementary School
}

\author{
Lindawati $^{1)}$, Sri Murdiyah ${ }^{2)}$, Sutansi $^{3)}$ \\ Elementary School Teacher Education Study Program of \\ Faculty of Science Education Universitas Negeri Malang \\ Semarang Street No.5,Malang,Indonesia ${ }^{1,2,3)}$ \\ lindawati9d7@gmail.com
}

\begin{abstract}
Indonesia is a country that is rich in culture, each region has cultural characteristics that make the diversity of the nation, one of which is the archipelago dance. However, the archipelago dance is less attractive to students and begin to be ignored and even forgotten by the younger generation, they are more familiar with modern dance than the archipelago dance. This development research aims to test the feasibility of a QR Code-based Rubita media in terms of attractiveness, validity, and practicality. The research method used is a modification of the Borg and Gall development model that includes stages (1) potential and problems, (2) data collection, (3) product design, (4) design validation, (5) design revision, (6) testing try the product, (7) product revision, (8) trial use. The results of the research and development of QR Code-based Rubita media show the level of validity of the material experts by $94 \%$, validation of media experts by $98 \%$, and validation from users (teachers) by $96 \%$ percentage of QR Code-based Rubita media including highly valid media. The results of product trials in the field show that the appearance of instructional media is very compatible with learning in elementary schools, with the combination of shapes and colors on the QR Code-based Rubita makes students very interested in participating in learning with these media.
\end{abstract}

Keywords: Rubita based on QR Code; Cultural Diversity; Elementary School

\begin{abstract}
Abstrak. Indonesia adalah negara yang kaya akan budaya, setiap daerah memiliki ciri khas budaya yang menjadikan keanekaragaman bangsa, salah satunya adalah tari nusantara. Namun, tari nusantara kurang diminati oleh siswa dan mulai diabaikan bahkan dilupakan oleh generasi muda, mereka lebih mengenal tari modern daripada tari nusantara. Penelitian pengembangan ini memiliki tujuan untuk menguji kelayakan media Rubita berbasis $Q R$ Code dari segi kemenarikan, kevalidan, dan kepraktisan. Metode penelitian yang digunakan adalah modifikasi dari model pengembangan Borg and Gall yang meliputi tahap (1) potensi dan masalah, (2) pengumpulan data, (3) desain produk, (4) validasi desain, (5) revisi desain, (6) uji coba produk, (7) revisi produk, (8) uji coba pemakaian. Hasil penelitian dan pengembangan media Rubita berbasis $Q R$ Code menunjukkan tingkat kevalidan dari ahli materi sebesar 94\%, validasi ahli media sebesar 98\%, dan validasi dari pengguna (guru) sebesar $96 \%$ persentase media Rubita berbasis $Q R$ Code termasuk media yang sangat valid. Hasil uji coba produk di lapangan menunjukkan bahwa tampilan media pembelajaran sangat sesuai dengan pembelajaran di Sekolah Dasar, dengan perpaduan bentuk dan warna-warni pada Rubita berbasis QR Code membuat siswa sangat tertarik untuk mengikuti pembelajaran dengan media tersebut.
\end{abstract}

Kata Kunci: Rubita Berbasis QR Code; Keberagaman Budaya; Sekolah Dasar 


\section{INTRODUCTION}

Indonesia is a rich country in terms of culture, each region has cultural characteristics that make the diversity of the nation, such as traditional clothing, traditional houses, musical instruments, archipelago weapons, regional languages, tribes, folk songs, and dance of the archipelago. This cultural wealth is the pride of all Indonesian people.

Archipelago dance is one of the cultural heritage that must be preserved. Archipelago dance is one of the cultural heritage which is closely related to the aspect of human life. In terms of type, dance can be divided into several groups based on regional origin or the specificity in which the dance originated (Ratih, 2001). Archipelago dance is an encyclopedia that stores everything that is considered important by the supporting community, full of philosophical messages, both spiritual, moral, and social aspects of the community (Sustiawati, 2011).

However, the archipelago dance is less desirable by students and begin to be ignored and even forgotten by the younger generation, they are more familiar with modern dance than the archipelago dance. The lack of interest in learning the material can be seen from students' complaints stating that archipelago dance material is considered difficult because it requires a lot of memorization. Also, the factors that cause the diversity of archipelago material are less liked by students because most teachers still deliver learning material verbally so the learning process tends to be boring and students find it difficult to understand the material presented

Based on the observation results made on October 3, 2019 showed a lack of media development, lack of utilization of learning facilities, and a lack of variety of learning methods applied, as well as teachers using poster-sized media about archipelago dance. Then, on December 9, 2019, interviews were conducted with grade IV teachers at SDN Gedog 2 Blitar City and continued observations to find out the availability of learning media for cultural diversity and their use in the learning process. The results of these interviews revealed that the media for cultural diversity in SDN Gedog 2 Blitar City was not optimal. Learning media are limited to images in the form of posters and utilize the surrounding environment as learning media. Besides, based on the results of observations of learning obtained information that students are still dominantly receive learning through lecture method. At first, the learning went well, but later it was seen an indication of the lack of student learning concentration. Some students begin to turn their attention to other things, such as chatting with friends, sleepy, crossing out books, daydreaming, and playing alone. It is indicated that the case of students with these learning activities can be assumed as a symptom that learning is less interesting and boring for students. 
There is a need for innovation in delivering material on the diversity of the archipelago dance to increase student interest in learning. One of the innovations that can attract students' attention in the learning process is to use creative and innovative media. Raharjo in (Kustandi \& Sutjipto, 2011) explained the understanding of the media is a container used to convey messages so that the recipient of the message is easier to understand the message or material delivered. By using media, the learning process will be more interesting. Kustiawan (2018) also revealed that learning media is everything that is used by teachers to deliver material to students, so students are interested in their interests and attention, stimulated their thoughts and feelings on learning activities to achieve learning objectives. The purpose of using media is to increase effectiveness and efficiency in teaching and learning activities, increase student motivation, as a variation of learning methods, and increase student activation in teaching and learning activities (Untari, 2017). In addition,learning objectives will be easily achieved because the material taught by the teacher will be clearer and easier to understand by students. Learning will be more meaningful for students if in the learning process used concrete objects or manipulative objects that more involve students' sense of sight. This is consistent with Piaget's cognitive theory that children's thinking at primary school age is at a concrete operational stage where mental activity is carried out on real or concrete objects and events (Sutarto, 2017). One object that can be used for learning is learning media.

Research on the level of achievement of knowledge that has been done by Ahmad in (Mahnun, 2012) shows that achievement through the sense of sight reaches $75 \%$, while through the sense of hearing only $13 \%$, whereas through other senses, such as taste, touch, smell, knowledge can only be obtained by $12 \%$. If the learning environment that is equipped with pictures has an impact 3 times stronger and deeper than words. Meanwhile, if images and words are combined, the impact is stronger than words alone.

The results of the study, provide an innovative idea to develop student learning media. The media development in this research is called QR Code based Rubita media. Rubita is the result of inspiration from rubik which has a unique shape to be played. Rubita has the advantages of being easy to carry (practical), having an attractive design for elementary students, having endurance so that it can be used repeatedly and its application can enhance a more vibrant learning atmosphere. QR Code based rubita has QR codes in every part of dance material. QR Code connects to supporting powerpoints and learning videos, so students will get deeper information related to the material. It is hoped that this development can foster the character of hard work through QR Code-based Rubita media. 


\section{RESEARCH METHODS}

In developing Rubita media as a learning medium in grade IV elementary school, the research used was research and development (R\&D). Sugiyono (2007) revealed that research and development is a research method for making a new product that has been improved, then testing the effectiveness of the product before use. In this development research, the product is a Rubita based QR Code media that is valid and practical by using the Borg and Gall model steps that have been modified by Sugiyono (2007) consisting of ten steps including: (1) potentials and problems, (2) data collection, (3) product design, (4) design validation, (5) design revisions, (6) product trials, (7) product revisions, (8) usage trials, (9) product revisions, and (10) ) mass production.

The test subjects in this study are as follows: media validator is a competent media expert, a material validator is competent material expert, user validator is grade IV teacher at SDN Gedog 2 Blitar City, subject of a small group of students in class IV Bendo 1 SDN Blitar City, and the user subject is grade IV students of SDN Gedog 2 Blitar City. Data collection techniques used were questionnaires, observations, and interviews. Interviews and observations were conducted at the beginning of the study, questionnaires were used to determine the feasibility of the media, and student questionnaires were used to determine students' responses to the media.
The data analysis technique used is quantitative and qualitative techniques. Quantitative fan qualitative analysis for product validity test refers to Akbar (2013) using the following formula.

$$
V a h=\frac{T s e}{T s h} \times 100 \%
$$

Notes:

$V a h=$ Expert Validation

$T s e=$ Total Empirical Score achieved

$T s h=$ Expected total Empirical Score

In addition, this study uses the Guttman and Likert scale to optimize data analysis.

\section{DISCUSSION}

\section{Product Description}

Rubita Media is an educational media consisting of 8 cubes arranged into one cube. Rubit media development pictures are as follows:

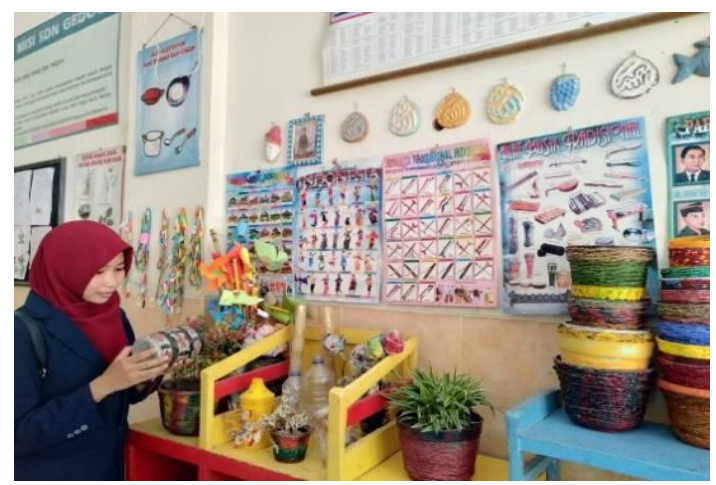

Picture 1. Media before it is developed

In the picture above, we can see the difference in media before it was developed. The initial media was only in the form of posters and as images. In the development media, dance and musical instruments are 
arranged more attractively with a combination of illustrated characters and using a combination of attractive colours.

Rubita was created to increase the students' motivation of grade IV in participating in learning in class. So that students will be excited and enthusiastic in learning. Rubita consists of 8 cubes arranged into a single cube, each cube measuring $6 \mathrm{~cm}$ $\mathrm{x} 6 \mathrm{~cm}$ so that the total size of the cube if it has been arranged into $12 \mathrm{~cm} \times 12 \mathrm{~cm}$. The material is packaged with short and clear sentences making it easier for students to understand the media. In addition, Rubita is equipped with a QR Code measuring $1 \mathrm{~cm} \times 1$ $\mathrm{cm}$ which contains supporting powerpoints and learning videos. Rubita is made based on $\mathrm{KD}$ and the learning objectives of the theme "Beautiful Togetherness" on the theme "Diversity of My Nation's Culture" in charge of social studies grade IV elementary school.

\section{Rubita Media}

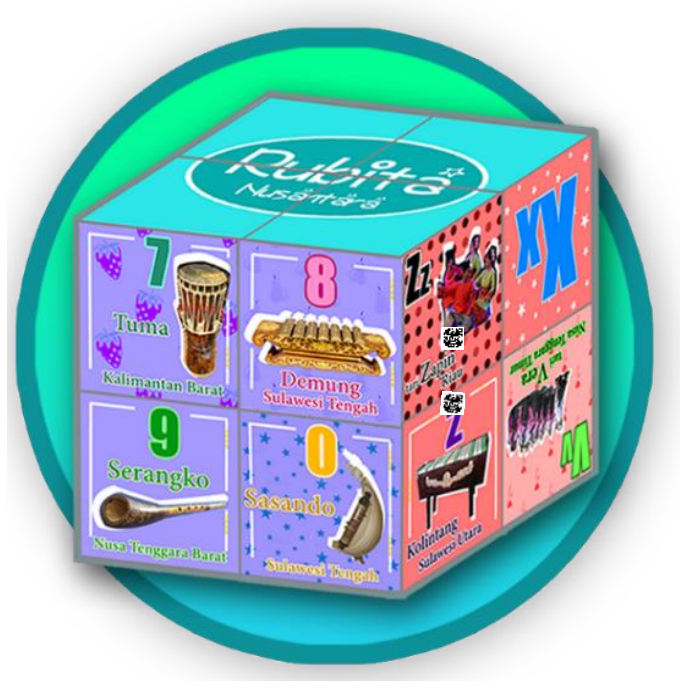

Picture 2. Rubita Products Based on QR Code

\section{Handbook of Application of Rubita}

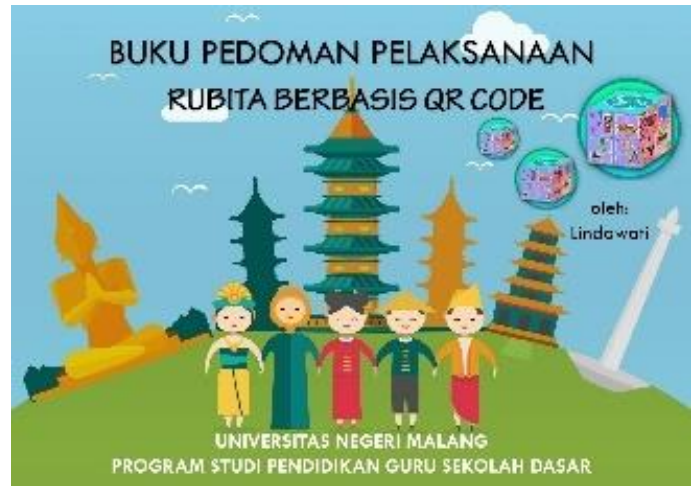

Picture 3. Handbook of Application of Rubita Based on QR Code

Rubita Media has advantages over other media. Rubita is designed with due regard to the practicality and durability of the media. Rubita is practical means easy to use (can be moved and carried) and in terms of time has a long durability so that it can be used repeatedly, because the material used in making Rubita is very light, not easily damaged, and durable. Rubita is also designed with images and colors that appeal to elementary students. The text uses language that is clear and easy to understand for grade IV elementary school students.

\section{Data Analysis of Material Validation}

In the aspect of content eligibility get a score of 14, the aspect of presentation worthiness gets a score of 15 , the aspect of language worthiness gets a score of 8 , and the aspect of hard work gets a score of 12 . The total score on all items obtained from the validation of material experts is 49 from a maximum score of 52 . 
The calculation results of the percentage calculation of validity from the results of the material experts are as follows.

$$
\begin{gathered}
\text { Vah }=\frac{\text { Tse }}{T s h} \times 100 \% \\
V a h=\frac{49}{52} \times 100 \%=95 \%
\end{gathered}
$$

Based on the calculation results obtained a percentage value of $95 \%$. According to Akbar, (2013) it can be concluded that the contents of the material in the Rubita-based QR Code media are classified as very valid criteria.

\section{Data Analysis of Material Validation}

In the aspect of the feasibility of the presentation get a score of 15 , in the aspect of language eligibility get a score of 8 , in the aspect of the feasibility of graphics get a score of 12 , and in the aspect of hard work get a score of 4 . The total score on all items obtained from the results of the validation of material experts amounted to 39 of the maximum score 40 .

The results of the calculation of the percentage of validity from the results of the media experts are as follows.

$$
\begin{gathered}
\text { Vah }=\frac{\text { Tse }}{T s h} \times 100 \% \\
V a h=\frac{39}{40} \times 100 \%=98 \%
\end{gathered}
$$

Based on the calculation results obtained a percentage value of $98 \%$. According to (Akbar, 2013), it can be concluded that the $Q R$ Code-based Rubita media is classified as a very valid criterion.

\section{User Validation Data Analysis}

In the aspect of content eligibility get a score of 14 , the aspect of presentation worthiness gets a score of 15 , in the aspect of language eligibility get a score of 8 , in the aspect of graphic eligibility get a score of 12 , and in the aspect of hard work get a score of 4. The total score on all items obtained from the validation results from material experts of 61 out of a maximum score of 64 . The results of the calculation of the percentage of validity from the results of the media experts are as follows.

$$
\begin{gathered}
\text { Vah }=\frac{T s e}{T s h} \times 100 \% \\
V a h=\frac{61}{64} \times 100 \%=96 \%
\end{gathered}
$$

Based on the calculation results obtained a percentage value of $96 \%$. According to (Akbar, 2013), it can be concluded that the QR Code-based Rubita media is classified as a very valid criterion.

\section{Data Analysis of Trial Results}

Product trials were conducted in two elementary schools. Small group trials were conducted at SDN Bendo 1 in Blitar City, while field trials were conducted at SDN Gedog 2 in Blitar City. The validation data are presented in Table 1. below. 
Table 1. Percentage of Product Trial Results

\begin{tabular}{lcc}
\hline \multicolumn{1}{c}{ Activity } & Percentage & \multicolumn{1}{c}{ criteria } \\
\hline $\begin{array}{l}\text { Small-Group } \\
\text { Trials }\end{array}$ & $100 \%$ & $\begin{array}{l}\text { Very practical } \\
\text { and interesting } \\
\text { Field Trial }\end{array}$ \\
\hline Average & $98 \%$ & $\begin{array}{l}\text { Very practical } \\
\text { and interesting }\end{array}$ \\
\hline
\end{tabular}

\section{Small-Group Trials}

Small group trials are conducted to minimize errors before field trials are conducted. The results of the small group trial evaluation state that the level of practicality and attractiveness of the product is $100 \%$, meaning that if interpreted into the range of 76 $\leq \mathrm{P} \leq 100$ (Yamasari, 2010) states the product is very practical and attractive and can be used without revision. In addition, students' responses to Rubita based on QR Code were very positive. Students feel happy and enthusiastic because the QR Code-based form of Rubita is very unique and interesting when it is played or used. So students do not get bored easily when using Rubita based on QR Code in learning. This small group trial also aims to fulfil one of the elements of good learning media, namely accuracy, where the product must be scientifically correct, current, and useful (Susanti, 2016).

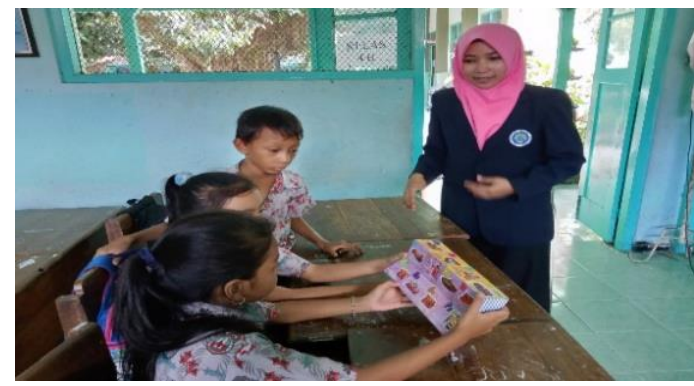

Picture 4. Small Group Trials

\section{Field Trial}

Field trials are conducted after the product has been perfected after a small group trial. The results of the field trial evaluation stated that the level of practicality and attractiveness of the product was $98 \%$, meaning that if interpreted in the range of $76 \leq$ $\mathrm{P} \leq 100$ (Yamasari, 2010) the product was very practical and attractive and could be used without revision. Based on field trials obtained several other findings: 1) Students are very enthusiastic and direct their attention to concentrate when the learning process with QR-based Rubita. This is shown with an enthusiastic attitude when using Rubita based on QR Code. 2) Students easily understand the material in Rubita based on QR Code that uses simple language. This can be seen when the teacher gives a question, students competing to immediately answer. 3) Students' thinking skills develop from simple to complex. With the supporting powerpoints and videos connected through the QR Code intermediaries, Rubita's QR Code based media can make students more critical of the material presented. This is in line with the opinion of Costa in (Dewi \& Riandi, 2016) argues that thinking skills are categorized in basic thinking skills and complex thinking skills. Basic thinking ability includes basic processes (basic processes) which are a picture of rational thought processes that contain a set of mental processes from simple to complex. 
Field trials are conducted after the product has been perfected after a small group trial. The results of the field trial evaluation stated that the level of practicality and attractiveness of the product was $98 \%$, meaning that if interpreted in the range of $76 \leq$ $\mathrm{P} \leq 100$ (Yamasari, 2010) the product was very practical and attractive and could be used without revision. Based on field trials obtained several other findings:

1) Students are very enthusiastic and direct their attention to concentrate when the learning process with QR-based Rubita. This is shown with an enthusiastic attitude when using Rubita based on QR Code.

2) Students easily understand the material in Rubita based on QR Code that uses simple language. This can be seen when the teacher gives a question, students competing to immediately answer.

3) Students' thinking skills develop from simple to complex. With the supporting powerpoints and videos connected through the QR Code intermediaries, Rubita's QR Code based media can make students more critical of the material presented. This is in line with the opinion of Costa in (Dewi \& Riandi, 2016) argues that thinking skills are categorized in basic thinking skills and complex thinking skills. Basic thinking ability includes basic processes (basic processes) which is a picture of rational thought processes that contain a set of mental processes from simple to complex.
4) Social interactions and discussions emerge. This can be seen in the group of students working together to solve the challenges posed by the teacher. Students help each other find the right answers. So, this brings up the character of hard work in students.This has fulfilled the learning media function revealed by Arsyad (2011), namely (a) attention function, (b) effective function, (c) cognitive function, and (d) compensatory function. In addition, students are increasingly eager to follow the learning process and are not easily bored. And also in accordance with the opinion of Ali (2005) revealed that the use of computer-assisted learning media has a significant influence on the attractiveness of students to learn the competencies being taught.

This QR Code-based rubita increases student involvement in learning process. Students are challenged to continue to be active and enthusiastic in accepting questions from the teacher. Each group works together to answer questions from the teacher. QR Codebased rubita can be used as a learning medium to support learning in the classroom, this is in line with Hamalik's opinion in (Arsyad, 2011) which states that the use of instructional media in the teaching and learning process can arouse new desires and interests, arouse motivation and stimulate learning activities, and even brings psychological influence on students. Based on validity test, practicality, 
and supported by the attractiveness test, this Rubita based QR Code product is suitable for use in learning and meets the criteria of good learning media. Good learning media selection criteria according to (Arsyad, 2011) are: (1) clear and neat, (2) clean and interesting, (3) fit the target, (4) relevant to the topic being taught, (5) in accordance with the objectives learning, (6) practical, flexible, and enduring, (7) good quality, and (8) the size is in accordance with the learning environment.

Development that occurs is also very visible. When testing a small group based on the QR Code Rubita increases student enthusiasm in learning. Students can work together with their group friends and improve the character of hard work in learning.

When field testing the product development program based on QR Code Rubita was seen again, when the teacher gave a question and answer question at the end of learning through supporting powerpoints, the competitive spirit of students was very visible. Students compete with each other and compete in answering these questions. So learning is very fun.

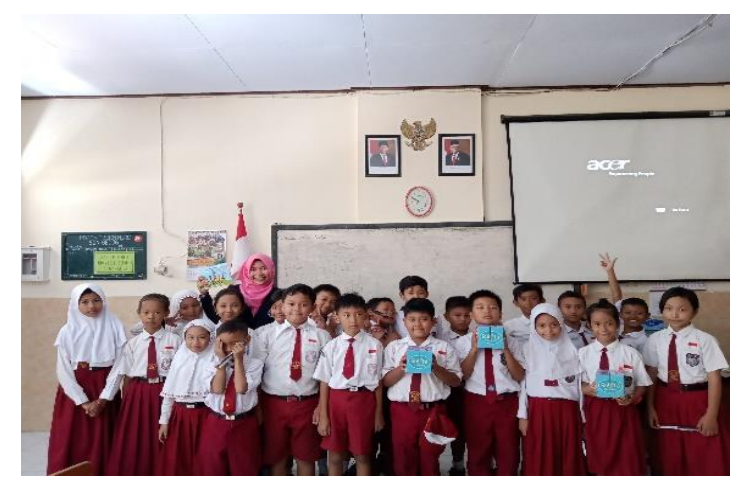

Gambar 5. Filed Trial

\section{Limitation}

The limitations of this media are 1) Small group trials were carried out in class IV B SDN Bendo 1 Blitar City and field trials were conducted in class IV SDN Gedog 2 Blitar City, 2) QR Code-based rubita was only centered on subtema 1 "Diversity of My Nation's Culture" on theme 1 "Beautiful Togetherness" IPS content on the material of dance and music of the archipelago, 3) The validity of the product is based on the assessment of material experts, media experts, while the practicality of the product is based on user ratings and the attractiveness of the product based on student questionnaire responses.

\section{Long-term plan}

QR Code-based rubita should be developed more broadly by adding more topics to the material for the diversity of the Nation's Culture to make it more interesting and gain deeper knowledge. QR Code based Rubita products can also be developed by adding even more sophisticated technologies such as augmented reality (AR) so that they can be visualized as if they were real, which will make learning more fun.

The results of Rubita-based QR code research are in line with the results of research conducted by Harnanto (2016) that the success of students in learning before the use of tools averaged $54.56(56.77 \%)$, but after using the tools the success rate reached an average of 
$90.52(94.19 \%)$ in his research using mathematical box media. In addition, the use of $\mathrm{QR}$ code is also in line with research conducted by Mawaddah (2018) stating that interactive learning media assisted by $\mathrm{QR}$ Code is able to integrate realia media, image media, and video media in nail plant material. When students use this interactive media, they are involved audio, visual, and kinetic, so that with this involvement students can easily understand information. And also according to Lindawati in Rilianti (2019) in her research revealed that by learning interactive powerpoints and learning videos through $\mathrm{QR}$ code makes learning more fun.So rubita media based on QR code can make learning more fun

\section{CONCLUSION}

Research and development of QR Codebased Rubita products by strengthening the character of hard work has been validated by one material expert, one media expert, one user, 9 students at SDN Bendo 1 in Blitar City, and 24 students at SDN Gedog 2 in Blitar City. According to the expert material Rubita products based on QR Code are very valid, which includes the appropriateness of content, the appropriateness of presentation, the appropriateness of language, and the character of the hard work of the Rubita based on QR Code, obtaining a percentage of $95 \%$. According to media experts Rubita's QR Codebased products are very valid, which includes the appropriateness of presentation, the appropriateness of graphics, and the hard work character of Rubita based on QR Code, obtaining a percentage of $98 \%$. According to the teacher as a user of a Rubita based QR Code product, it is very valid, which includes content worthiness, presentation worthiness, language worthiness, graphic worthiness, and hard work character getting a $96 \%$ percentage. According to data from the results of a small group trial of 9 students the QR Code based Rubita product is very valid, obtaining a percentage of $100 \%$. Meanwhile, according to data from the field trial results of 24 students the QR Code-based Rubita product is very valid, obtaining a percentage of $98 \%$.

From the results above it can be concluded that the QR Code-based Rubita product can be used as a learning media for class IV Substance of Cultural Diversity My Nation is included in the category of valid, practical, and attractive so that it is suitable for use in the learning process

\section{REFERENCES}

[1] Akbar, S. (2013). Instrumen Perangkat Pembelajaran, Bandung: PT. Remaja Rosdakarya.

[2] Ali, M. (2005). Pengembangan bahan pembelajaran berbantuan komputer untuk memfasilitasi belajar mandiri dalam mata diklat penerapan konsep dasar listrik dan elektronika di SMK. Laporan Penelitian Research Grant PHK A2 Jurusan Pendidikan Teknik Elektro FT UNY.

[3] Arsyad, A. (2011). Media pembelajaran. Jakarta: PT Raja Grafindo Persada. 
[4] Dewi, N., \& Riandi, R. (2016). Analisis kemampuan berpikir kompleks siswa melalui pembelajaran berbasis masalah berbantuan mind mapping. EDUSAINS, 8(1), 98-107.

[5] Harnanto, S. (2016). Alat Peraga Kotak Belajar Ajaib (Kobela) Dalam Pembelajaran Matematika Materi Perkalian Dan Pembagian Sekolah Dasar. Jurnal Ilmiah Pendidikan Dasar, 3(1), 33-42.

[6] Kustandi, C., \& Sutjipto, B. (2011). Media pembelajaran manual dan digital. Bogor: Ghalia Indonesia, 173.

[7] Kustiawan, U. (2018). Sumber dan Media Pembelajaran Anak Usia Dini. Karya Dosen Fakultas Ilmu Pendidikan UM.

[8] Mahnun, N. (2012). Media pembelajaran (kajian terhadap langkah-langkah pemilihan media dan implementasinya dalam pembelajaran). An-Nida', 37(1), 27-34.

[9] Mawaddah, K. (2018). QUICK RESPONSE CODE (QR CODE)-ASSISTED INTERACTIVE MEDIA ON PTERYDOPHYTA FOR HIGH SCHOOL STUDENT. Jurnal Pendidikan Biologi, 9(1), 23-30.

[10] Ratih, E. E. W. (2001). Fungsi Tari sebagai Seni Pertunjukan (The Function of Dance as A Performing Art). Harmonia Jurnal Pengetahuan Dan Pemikiran Seni. Harmonia.

[11] Rilianti, A. P. (2019). Prosiding Seminar Nasional Pendidikan Dasar (SENADA) STKIP Al Hikmah 2019.

[12] Sugiyono, M. (2007). Kualitataif dan R\&D, Bandung: Alfabeta, 2010. Sugiyono, Metode Penelitian Kuantitatif Kualitatif Dan $R \& D$ Bandung: Alfabeta.

[13] Susanti, R. D. (2016). Studi Analisis Materi Ajar "Buku Teks Pelajaran "Pada Mata Pelajaran Bahasa Arab di Kelas Tinggi Madrasah Ibtidaiyah. Arabia, 5(2).

[14] Sustiawati, N. L. (2011). Kontribusi Seni Tari Nusantara dalam Membangun Pendidikan Multikultur. Jurnal Mudra, 26(2), 126-135.
[15] Sutarto, S. (2017). Teori kognitif dan implikasinya dalam pembelajaran. Islamic Counseling: Jurnal Bimbingan Konseling Islam, 1(2), 1-26.

[16] Untari, E. (2017). Problematika dan Pemanfaatan Media Pembelajaran Sekolah Dasar Di Kota Blitar. JURNAL PENDIDIKAN DASAR PERKHASA: Jurnal Penelitian Pendidikan Dasar, 3(1), 259-270.

[17] Yamasari, Y. (2010). Pengembangan media pembelajaran matematika berbasis ICT yang berkualitas. Seminar Nasional Pascasarjana X-ITS. FMIPA Unesa. 